\title{
Simple and multiple resistances to viruses in cowpea genotypes
}

\author{
José Albersio Araujo Lima(1), Ana Kelly Firmino da Silva(1), Maria do Livramento Aragão(1), \\ Nádia Rutielly de Araújo Ferreira(1) and Elizita Maria Teófilo(2)
}

\begin{abstract}
(1)Universidade Federal do Ceará (UFC), Departamento de Fitotecnia, Laboratório de Virologia Vegetal, Caixa Postal 6.046, CEP60451-970 Fortaleza, CE, Brazil. E-mail: albersio@ufc.br, kelly.firmino@gmail.com, prin_aragao@yahoo.com.br, rutynhaferreirah@yahoo.com.br (2)UFC, Departamento de Fitotecnia, Laboratório de Sementes. E-mail: elizita@ufc.br
\end{abstract}

\begin{abstract}
The objective of this work was to identify new sources of simple and multiple resistances to Cowpea severe mosaic virus (CPSMV), Cowpea aphid-borne mosaic virus (CABMV) and Cucumber mosaic virus (CMV) isolates in cowpea (Vigna unguiculata). Thirty-three genotypes from the germplasm bank of Universidade Federal do Ceará were tested as to their resistance to four CPSMV isolates, two CABMV isolates and one CMV isolate. Twenty-five days after the first virus inoculations, all inoculated plants, including the asymptomatic ones, were tested by serology. Genotypes were classified as: immune, plants without symptoms and negative serology; resistant, plants with mild mosaic and positive serology; susceptible, plants with mosaic and positive serology; and highly susceptible, plants with severe mosaic, other systemic symptoms, including systemic necrosis, and positive serology. Simple and multiple resistances to viruses were identified among the evaluated genotypes, but none of them showed multiple immunities to all isolates. Four genotypes showed immunity to all CPSMV isolates, two were immune to CABMV and two showed immunity to CMV. Eleven genotypes showed multiple resistances to two viruses, allowing for the development of new cultivars with more stable and broader resistance. Genotypes Purple Knuckle Hull-55, MNC-03-731C-21 and CNCx284-66E show resistance to CABMV, even when inoculated with CMV.
\end{abstract}

Index terms: Cowpea aphid-borne mosaic virus, Cowpea severe mosaic virus, Cucumber mosaic virus, Vigna unguiculata, serology, virus control.

\section{Resistência simples e múltipla a vírus em genótipos de caupi}

Resumo - O objetivo deste trabalho foi identificar novas fontes de resistência simples e múltiplas em genótipos de feijoeiro caupi (Vigna unguiculata) a isolados de Cowpea severe mosaic virus (CPSMV), Cowpea aphid-borne mosaic virus (CABMV) and Cucumber mosaic virus (CMV). Trinta e três genótipos do Banco de Germoplasma da Universidade Federal do Ceará foram classificados quanto a sua resistência a quatro isolados de CPSMV, dois de CABMV e um de CMV. Após 25 dias da primeira inoculação dos isolados, todas as plantas que sofreram inoculação, incluindo as assintomáticas, foram testadas por meio de sorologia. Os genótipos foram classificados como: imune, plantas assintomáticas e sorologia negativa; resistentes, plantas com mosaico leve e sorologia positiva; suscetível, plantas com mosaico e sorologia positiva; altamente suscetível, plantas com mosaico severo, outros sintomas sistêmicos, como necrose sistêmica, e sorologia positiva. Foram identificadas fontes de resistência simples e múltipla às viroses, nos genótipos avaliados; no entanto, nenhum deles apresentou imunidade múltipla aos três vírus. Quatro genótipos apresentaram imunidade aos isolados de CPSMV, dois aos isolados de CABMV e dois ao CMV. Onze genótipos apresentaram resistência múltipla a dois vírus, o que possibilita o desenvolvimento de novas cultivares com resistência mais abrangente e estável. Os genótipos Purple Knuckle Hull-55, MNC-03-731C-21 e CNCx284-66E mostram resistência ao CABMV, mesmo após a inoculação do CMV.

Termos para indexação: Cowpea aphid-borne mosaic virus, Cowpea severe mosaic virus, Cucumber mosaic virus, Vigna unguiculata, sorologia, controle de vírus.

\section{Introduction}

Cowpea [Vigna unguiculata (L.) Walp., subspecies unguiculata] is a major source of protein with considerable importance for human nutrition in the semiarid and tropical regions of Northeastern Brazil. The North and Northeast of Brazil are the largest producer areas, and the state of Ceará is considered the greatest producer in the country (Freire Filho et al., 2005; Lima et al., 2005b). Therefore, this leguminous crop is of strategic importance for small farmers and an option for the agribusiness of the North and Northeast of Brazil.

Several factors affect the productivity of cowpea, mainly the incidence of infectious diseases. The diseases caused by viruses have been responsible for 
great damage, causing serious losses in crop yield in several countries, including Brazil (Hampton et al., 1997; Gowda et al., 2000; Singh et al., 2000; Kang et al., 2005; Lima et al., 2005b; Pio-Ribeiro et al., 2005; Ghorbani et al., 2008). Viral diseases have been considered one of the most important sanitary problems in cowpea in the state of Ceará, causing serious reductions in crop productivity (Lima \& Nelson, 1973; Lima et al., 2005b).

Worldwide, up to 20 viruses have been reported to occur in cowpea (Hampton et al., 1997; Lima et al., 2005b). However, only four are known to infect cowpea in the Northeast of Brazil: Cowpea severe mosaic virus (CPSMV), family Comoviridae, genus Comovirus; Cowpea aphid-borne mosaic virus (CABMV), family Potyviridae, genus Potyvirus; Cucumber mosaic virus (CMV), family Bromoviridae, genus Cucumovirus; and Cowpea golden mosaic virus (CGMV), family Geminiviridae, genus Begomovirus (Lima et al., 2005b).

Besides infections caused by isolated viruses, mixed infections with more than one virus have been observed with relative frequency in cowpea under field conditions (Pio-Ribeiro et al., 1978; Lima et al., 2005b). Dwarfing of cowpea caused by a synergistic infection of Blackeye cowpea mosaic virus (BlCMV), of the genus Potyvirus, with CMV was considered a devastating disease in Georgia, Alabama and South Carolina (Pio-Ribeiro et al., 1978). Similarly, simultaneous infections of CABMV and CMV have been reported to frequently occur, with high degree of incidence in Brazil, causing serious damages to crop productivity (Lima et al., 2005b). Therefore, the selection of cowpea cultivars with multiple resistances is fundamental to control mixed infections (Anderson et al., 1996).

The development of resistant cultivars has been universally considered the most effective method to control diseases caused by viruses in cowpea, indicating that an increase in the number of virus-resistant genotypes will generate more alternatives for breeders to produce resistant cultivars (Lima et al., 1986, 2005a; Hampton et al., 1997; Assunção et al., 2005).

The objective of this work was to identify new sources of simple and multiple resistances in cowpea genotypes to four CPSMV isolates, two CABMV isolates and one CMV isolate.

\section{Materials and Methods}

The virus isolates used in this study belong to the bank of active plant viruses of Laboratório de Virologia Vegetal of Universidade Federal do Ceará (UFC), and included four isolates of CPSMV, two of CABMV and one of CMV. The following CPSMV isolates were used in the evaluation of the cowpea genotypes: $\mathrm{CPSMV}_{\mathrm{CE}}$, the first characterized isolate obtained from cowpea in Ceará (Lima \& Nelson, 1973); CPSMV $_{\mathrm{MC}}$, an isolate with the capacity to infect 'Macaibo', a cowpea cultivar immune to most isolates of CPSMV (Lima et al., 1998); $\mathrm{CPSMV}_{\mathrm{CROT}}$, isolated from Crotalaria paulinea $\mathrm{L}$. in the state of Maranhão (Lima et al., 2005a); and CPSMV ${ }_{\mathrm{PB}}$, an isolate recently obtained from cowpea in the state of Paraíba. The CABMV isolates used were also recently obtained from cowpea in the cities of Cascavel $\left(\mathrm{CABMV}_{\mathrm{CASC}}\right)$ and Fortaleza $\left(\mathrm{CABMV}_{\mathrm{FORT}}\right)$, in Ceará. The CMV isolate was obtained from an experimental cowpea field in Fortaleza. Virus identification was confirmed by serology, and all viruses were maintained under greenhouse conditions by periodical mechanical inoculations and monitored by serology.

Thirty-three cowpea genotypes were evaluated against CPSMV $_{\mathrm{CE}}, \mathrm{CPSMV}_{\mathrm{CROT}}, \mathrm{CPSMV}_{\mathrm{MC}}, \mathrm{CPSMV}_{\mathrm{PB}}$, $\mathrm{CABMV}_{\mathrm{CASC}}, \mathrm{CABMV}_{\mathrm{FORT}}$, and $\mathrm{CMV}$, undergreenhouse conditions (Lima \& Nelson, 1973; Lima et al., 2005a). Genotypes were grown on a sterile mixture of natural soil with organic matter. Then, eight plants of each cowpea genotype were inoculated with each virus isolate six days after planting and were inspected daily for symptoms. Ten days after inoculation, plants that did not exhibit symptoms were re-inoculated and two non-inoculated healthy plants of each genotype were maintained as controls. Twenty-five days after the first virus inoculations, all inoculated plants, including the asymptomatic ones, were tested by serology in double immune diffusion for CPSMV isolates and by indirect enzyme-linked immunosorbent assay (Elisa) for CABMV and CMV isolates (Almeida \& Lima, 2001). Both serological tests were performed according to Almeida \& Lima (2001), and the results for Elisa were considered as positive when the absorbance values were over two and a half the average values obtained for the extracts from the healthy cowpea plants used as negative controls. According to the symptoms and the serological results, the cowpea genotypes inoculated with the virus isolates were classified as: immune (extreme resistance), plants without symptoms and 
negative for serology; resistant, plants with mild mosaic and positive for serology; susceptible, plants with mosaic and positive for serology; and highly susceptible, plants with severe mosaic, other systemic symptoms, including systemic necrosis, and positive for serology.

The immunity reactions of the genotypes 'Macaibo', CNCx172-3E/P， CNCx284-66E， CNCx251-11E， CNCx251-76E, and CNCx249-272F to the CPSMV isolates were also confirmed by reverse transcription-polymerase chain reaction (RT-PCR), due to the low sensibility of double immune diffusion and the inadequacy of indirect Elisa for detecting the presence of viruses and CPSMV in infected plants, respectively. The inoculated cowpea genotypes were tested by RT-PCR using universal primers for the genus Comovirus: F, 5'-GCATGGTCCACWCAGGT-3' and R, 5'-YTCRAAWCCVYTRTTKGGMCCACA-3' (Camarço et al., 2009). Total RNA was extracted from leaf samples of inoculated plants, using the protocol developed by Rott \& Jelkmann (2001), with some modifications. The presence of RNA was confirmed by electrophoresis, and a first strand of cDNA was synthesized from the viral RNA using M-MLV Reverse Transcriptase (Promega Biotecnologia do Brasil Ltda., São Paulo, Brazil), according to the manufacturer's instructions. Viral fragments corresponding to a portion of the CP gene were amplified by PCR using $3 \mu \mathrm{L}$ of the cDNA, $5 \mu \mathrm{L}$ of buffer, $5 \mu \mathrm{L}$ of $\mathrm{MgCl}_{2}\left(25 \mathrm{mmol} \mathrm{L}^{-1}\right)$, $1 \mu \mathrm{L}$ of the mixture of desoxinucleotides $\left(0.01 \mathrm{~mol} \mathrm{~L}^{-1}\right)$, 1 unit of Taq DNA polymerase and 25 pmol of each primer (Camarço et al., 2009). PCR amplification was performed with initial heating at $94^{\circ} \mathrm{C}$ for $5 \mathrm{~min}$, followed by 30 cycles of denaturizing $\left(94^{\circ} \mathrm{C}\right.$ for 1 min), annealing $\left(41^{\circ} \mathrm{C}\right.$ for $\left.2 \mathrm{~min}\right)$ and extension $\left(72^{\circ} \mathrm{C}\right.$ for $1 \mathrm{~min}$ ), with final extension at $72^{\circ} \mathrm{C}$ for $5 \mathrm{~min}$. The amplified products were visualized in $1 \%$ agarose gel stained with ethidium bromide under UV light.

The genotypes that showed immunity or resistance to CABMV were also evaluated against simultaneous inoculation of CABMV and $\mathrm{CMV}$, considering the frequency and severity of simultaneous infections of these viruses, which cause serious damages in cowpea productivity (Lima et al., 2005b). Eight plants of each of the cowpea genotypes, Purple Knuckle Hull-55, MNC-03-731C-21 and CNCx284-66E, were simultaneously inoculated with $\mathrm{CABMV}_{\mathrm{CASC}}$ and CMV, six days after planting. The double inoculated plants were inspected daily for symptom reactions, and 25 days after viral inoculation, all inoculated plants were tested by indirect Elisa, using antisera, against CABMV and CMV, according to Almeida \& Lima (2001).

\section{Results and Discussion}

Different sources of simple and multiple immunity (extreme resistance) and resistance to CMV, CPSMV and CABMV isolates were identified in the evaluated cowpea genotypes (Tables 1 and 2). The resistance mechanism sometimes included tolerance or systemic presence of the virus without symptoms, which merely delayed symptom expression after inoculation, followed by mild symptoms. Although the genotype CNCx284-66E was shown to be immune to all CPSMV and CABMV isolates, and the genotype CNCx251-11E showed immunity to CMV and CPSMV isolates, none of the evaluated genotypes showed immunity to CABMV, CPSMV, and CMV simultaneously.

Based on the symptom reactions and on the serological results, 30 genotypes only showed mild mosaic after inoculation with CMV, indicating resistance to the virus. Plants of the genotypes BR-1 Poty, CNCx251-11E and Paulistinha did not show symptoms after CMV inoculation, and the virus was not detected by Elisa.

The genotypes Purple Knuckle Hull-55, MNC-03-731C-21 and CNCx284-66E showed resistance or immunity to both CABMV isolates. However, CABMV $\mathrm{CASC}_{\mathrm{C}}$ was more severe than $\mathrm{CABMV}_{\text {FORT }}$ in the other evaluated cowpea genotypes (Table 1). According to the symptom reactions, $70 \%$ of the genotypes were immune or resistant to $\mathrm{CABMV}_{\mathrm{FORT}}$ and only $33 \%$ showed immunity or resistance to $\mathrm{CABMV}_{\mathrm{CASC}}$. Although immunity or extreme resistance to CABMV isolates is probably controlled by the same genes, the results obtained indicate genetic variability among the CABMV isolates (Tables 1 and 2).

Considering the frequency and the severity with which simultaneous infections of CABMV and CMV have been occurring in Ceará (Lima et al., 2005b), the selection of resistant cowpea cultivars for controlling this double infection is of great importance. Anderson et al. (1996) showed that the resistance to the effect of the synergistic infection caused by BlCMV and CMV could be obtained avoiding the BlCMV infection, indicating that breeders should use cowpea genotypes 
with high resistance to viruses from the genus Potyvirus in the production of cowpea cultivars resistant to mixed infection. The immunity and resistance to CABMV identified in Purple Knuckle Hull-55, MNC-03-731C-21 and $\mathrm{CNCx} 284-66 \mathrm{E}$ were maintained even when the genotypes were inoculated with CMV. No symptoms and no viruses were detected 25 days after simultaneous inoculation with $\mathrm{CABMV}_{\mathrm{CASC}}$ and $\mathrm{CMV}$.

The symptom reactions and the serological results showed great biological differences among CPSMV isolates when inoculated in the cowpea genotypes. Although the isolate $\mathrm{CPSMV}_{\mathrm{MC}}$ infected the Macaibo cultivar, which is immune to all other CPSMV isolates, it caused less severe symptoms on the other cowpea genotypes than the other CPSMV isolates (Table 1), confirming previous studies (Camarço et al., 2009).

The symptoms caused by $\mathrm{CPSMV}_{\mathrm{CE}}, \mathrm{CPSMV}_{\mathrm{CROT}}$ and $\mathrm{CPSMV}_{\mathrm{PB}}$ varied from mosaic to severe mosaic with systemic necrosis, and plant death showing small variation among them. Differently from 'Macaibo', genotypes CNCx284-66E, CNCx251-11E, CNCx251-76E, CNCx249-272F and CNC 0434 were immune to all CPSMV isolates, including CPSMV $_{\mathrm{MC}}$. The exception was CNCx172-3E/P, which was similar to 'Macaibo'. Immunity or extreme resistance was determined by the absence of symptoms and by negative results in double immune diffusion tests of inoculated plants, which was confirmed by PCR. Although a

Table 1. Symptoms $(\mathrm{Sy})^{(1)}$, serological results $(\mathrm{Se})$ and behavior $(\mathrm{Be})^{(2)}$ of 33 cowpea (Vigna unguiculata) genotypes from the germplasm bank of Universidade Federal do Ceará (UFC), inoculated with isolates of Cucumber mosaic virus (CMV), Cowpea aphid borne mosaic virus (CABMV), and Cowpea severe mosaic virus (CPSMV).

\begin{tabular}{|c|c|c|c|c|c|c|c|c|c|c|c|c|c|c|c|}
\hline \multirow[t]{2}{*}{ Genotype } & \multirow{2}{*}{$\begin{array}{c}\text { UFC } \\
\text { bank number }\end{array}$} & \multicolumn{2}{|c|}{ CMV } & \multicolumn{2}{|c|}{$\mathrm{CABMV}_{\mathrm{CASC}}$} & \multicolumn{2}{|c|}{ CABMV $_{\text {FORT }}$} & \multicolumn{2}{|c|}{$\mathrm{CPSMV}_{\mathrm{CE}}$} & \multicolumn{2}{|l|}{ CPSMV $_{\text {CROT }}$} & \multicolumn{2}{|c|}{$\mathrm{CPSMV}_{\mathrm{MC}}$} & \multicolumn{2}{|l|}{$\mathrm{CPSMV}_{\mathrm{PB}}$} \\
\hline & & Sy Se & $\mathrm{Be}$ & Sy Se & $\mathrm{Be}^{(2)}$ & Sy Se & $\mathrm{Be}^{(2)}$ & Sy Se & $\mathrm{Be}^{(2)}$ & Sy Se & $\mathrm{Be}^{(2)}$ & Sy Se & $\mathrm{Be}^{(2)}$ & Sy Se & $\mathrm{Be}^{(2)}$ \\
\hline AU94 4180701 & CE 176 & $\mathrm{mM}(+)$ & $\mathrm{R}$ & $\mathrm{M}(+)$ & $\mathrm{S}$ & $\mathrm{M}(+)$ & $\mathrm{S}$ & sM,Bl (+) & $\mathrm{hS}$ & $\mathrm{sM}, \mathrm{Bl}(+)$ & $\mathrm{hS}$ & $\mathrm{M}(+)$ & $\mathrm{S}$ & $\mathrm{sM}, \mathrm{Bl}(+)$ & $\mathrm{hS}$ \\
\hline BR 1 Poty & CE 611 & NS (-) & I & $\mathrm{M}(+)$ & $\mathrm{S}$ & $\mathrm{mM}(+)$ & $\mathrm{R}$ & $\mathrm{sM}, \mathrm{Bl}(+)$ & $\mathrm{hS}$ & M (+) & $\mathrm{S}$ & $\mathrm{mM}(+)$ & $\mathrm{R}$ & M (+) & $\mathrm{S}$ \\
\hline BRS Punjante & CE 940 & $\mathrm{mM}(+)$ & $\mathrm{R}$ & $\mathrm{mM}(+)$ & $\mathrm{R}$ & NS (-) & $\mathrm{R}$ & sM,Bl (+) & $\mathrm{hS}$ & $\mathrm{M}(+)$ & $\mathrm{S}$ & $\mathrm{mM}(+)$ & $\mathrm{S}$ & sM,Bl (+) & $\mathrm{hS}$ \\
\hline BRS Rouxinol & CE 937 & $\mathrm{mM}(+)$ & $\mathrm{R}$ & $\mathrm{mM}(+)$ & $\mathrm{R}$ & $\mathrm{mM}(+)$ & $\mathrm{R}$ & $\mathrm{mM}(+)$ & $\mathrm{R}$ & $\mathrm{mM}(+)$ & $\mathrm{R}$ & $\mathrm{mM}(+)$ & $\mathrm{R}$ & $\mathrm{mM}(+)$ & $\mathrm{R}$ \\
\hline CB 3 & CE 423 & $\mathrm{mM}(+)$ & $\mathrm{R}$ & $\mathrm{M}(+)$ & $\mathrm{S}$ & $\mathrm{mM}(+)$ & $\mathrm{R}$ & $\mathrm{sM}, \mathrm{Bl}(+)$ & $\mathrm{hS}$ & $\mathrm{sM}, \mathrm{Bl}(+)$ & $\mathrm{hS}$ & $\mathrm{M}(+)$ & $\mathrm{S} \mathrm{s}$ & sM,Bl,LDit (+) & $\mathrm{hS}$ \\
\hline CE $31 \times$ CE 25 & CE 566 & $\mathrm{mM}(+)$ & $\mathrm{R}$ & $\mathrm{mM}(+)$ & $\mathrm{R}$ & NS (-) & $\mathrm{R}$ & $\mathrm{M}(+)$ & $\mathrm{S}$ & M (+) & $\mathrm{S}$ & $\mathrm{mM}(+)$ & $\mathrm{R}$ & M (+) & $\mathrm{S}$ \\
\hline CNC 0434 & CE 632 & $\mathrm{M}(+)$ & $\mathrm{S}$ & $\mathrm{M}(+)$ & $\mathrm{S}$ & $\mathrm{M}(+)$ & $\mathrm{S}$ & NS (-) & I & NS (-) & I & NS (-) & I & NS (-) & I \\
\hline $\mathrm{CNCx} 249272 \mathrm{~F}$ & CE 877 & $\mathrm{mM}(+)$ & $\mathrm{R}$ & $\mathrm{mM}(+)$ & $\mathrm{R}$ & $\mathrm{mM}(+)$ & $\mathrm{R}$ & NS (-) & I & NS (-) & I & NS (-) & I & NS (-) & I \\
\hline $\mathrm{CNCx} 28466 \mathrm{E}$ & CE 681 & $\mathrm{mM}(+)$ & $\mathrm{R}$ & NS (-) & $\mathrm{I}$ & NS (-) & I & NS (-) & I & NS (-) & I & NS (-) & I & NS(-) & I \\
\hline CNCx172 3E/P & CE 654 & $\mathrm{mM}(+)$ & $\mathrm{R}$ & $\mathrm{mM}(+)$ & $\mathrm{R}$ & $\mathrm{mM}(+)$ & $\mathrm{R}$ & NS (-) & I & NS (-) & I & $\mathrm{mM}(+)$ & $\mathrm{R}$ & NS (-) & I \\
\hline $\mathrm{CNCx} 25111 \mathrm{E}$ & CE 790 & NS (-) & I & $\mathrm{mM}(+)$ & $\mathrm{R}$ & $\mathrm{mM}(+)$ & $\mathrm{R}$ & NS (-) & I & NS (-) & I & NS (-) & I & NS (-) & I \\
\hline $\mathrm{CNCx} 25160 \mathrm{E}$ & CE 796 & $\mathrm{mM}(+)$ & $\mathrm{R}$ & sM,Bl (+) & $\mathrm{hS}$ & $\mathrm{mM}(+)$ & $\mathrm{R}$ & sM,Bl,LDit (+) & $\mathrm{hS}$ & $\mathrm{sM}, \mathrm{Bl}(+)$ & $\mathrm{hS}$ & $\mathrm{M}(+)$ & $\mathrm{S} s$ & sM,B1,LDit (+) & $\mathrm{hS}$ \\
\hline $\mathrm{CNCx} 25176 \mathrm{E}$ & CE 798 & $\mathrm{mM}(+)$ & $\mathrm{R}$ & M (+) & $\mathrm{S}$ & $\mathrm{M}(+)$ & $\mathrm{S}$ & NS (-) & I & NS (-) & I & NS (-) & I & NS (-) & I \\
\hline Macaibo & CE 524 & $\mathrm{mM}(+)$ & $\mathrm{R}$ & $\mathrm{M}(+)$ & $\mathrm{S}$ & $\mathrm{mM}(+)$ & $\mathrm{R}$ & NS (-) & I & NS (-) & I & sM,Bl (+) & $\mathrm{hS}$ & NS (-) & I \\
\hline Marataoã & CE 933 & $\mathrm{mM}(+)$ & $\mathrm{R}$ & $\mathrm{mM}(+)$ & $\mathrm{R}$ & $\mathrm{mM}(+)$ & $\mathrm{R}$ & $\mathrm{mM}(+)$ & $\mathrm{R}$ & $\mathrm{mM}(+)$ & $\mathrm{R}$ & $\mathrm{mM}(+)$ & $\mathrm{R}$ & $\mathrm{mM}(+)$ & $\mathrm{R}$ \\
\hline Milagroso & CE 46 & $\mathrm{mM}(+)$ & $\mathrm{R}$ & $\mathrm{M}(+)$ & $\mathrm{S}$ & $\mathrm{mM}(+)$ & $\mathrm{R}$ & $\mathrm{M}(+)$ & $\mathrm{S}$ & $\mathrm{M}(+)$ & $\mathrm{S}$ & $\mathrm{M}(+)$ & $\mathrm{S}$ & $\mathrm{sM}, \mathrm{Bl}(+)$ & $\mathrm{hS}$ \\
\hline MNC 0372011 & CE 178 & $\mathrm{mM}(+)$ & $\mathrm{R}$ & $\operatorname{LL}(-)$ & $\mathrm{R}$ & $\mathrm{LL}, \mathrm{mM}(+)$ & $\mathrm{R}$ & $\mathrm{sM}, \mathrm{Bl}(+)$ & $\mathrm{hS}$ & $\mathrm{sM}, \mathrm{Bl}(+)$ & $\mathrm{hS}$ & $\mathrm{mM}(+)$ & $\mathrm{R} s$ & sM,Bl,LDit (+) & $\mathrm{hS}$ \\
\hline MNC $03731 \mathrm{C} 21$ & CE 949 & $\mathrm{mM}(+)$ & $\mathrm{R}$ & NS (-) & I & $\mathrm{mM}(+)$ & $\mathrm{R}$ & $\mathrm{SM}(+)$ & $\mathrm{S}$ & $\mathrm{sM}, \mathrm{Bl}(+)$ & $\mathrm{hS}$ & $\mathrm{M}(+)$ & $\mathrm{S}$ & $\mathrm{sM}, \mathrm{Bl}(+)$ & $\mathrm{hS}$ \\
\hline Paulistinha & CE 939 & NS (-) & $\mathrm{I}$ & $\mathrm{M}(+)$ & $\mathrm{S}$ & $\mathrm{mM}(+)$ & $\mathrm{R}$ & $\mathrm{sM}, \mathrm{Bl}(+)$ & $\mathrm{hS}$ & $\mathrm{M}(+)$ & $\mathrm{S}$ & $\mathrm{mM}(+)$ & $\mathrm{S}$ & $\mathrm{sM}, \mathrm{Bl}(+)$ & $\mathrm{hS}$ \\
\hline Pingo de Ouro & CE 930 & $\mathrm{mM}(+)$ & $\mathrm{R}$ & $\mathrm{M}(+)$ & $\mathrm{S}$ & $\mathrm{M}(+)$ & $\mathrm{S}$ & $\mathrm{SM}, \mathrm{Bl}(+)$ & $\mathrm{hS}$ & sM,Bl(+) & $\mathrm{hS}$ & $\mathrm{M}(+)$ & $\mathrm{S} s$ & sM,Bl,LDit (+) & $\mathrm{hS}$ \\
\hline Pitiúba & CE 31 & $\mathrm{mM}(+)$ & $\mathrm{R}$ & $\mathrm{M}(+)$ & $\mathrm{S}$ & $\mathrm{M}(+)$ & $\mathrm{S}$ & $\mathrm{sM}, \mathrm{Bl}(+)$ & $\mathrm{hS}$ & sM,Bl,LDit (+) & $\mathrm{hS}$ & $\mathrm{mM}(+)$ & $\mathrm{R} s$ & sM,Bl,LDit (+) & $\mathrm{hS}$ \\
\hline Purple Knuckle Hull 55 & CE 113 & $\mathrm{mM}(+)$ & $\mathrm{R}$ & NS (-) & I & NS (-) & I & $\mathrm{sM}, \mathrm{Bl}(+)$ & $\mathrm{hS}$ & sM,Bl,LDit (+) & $\mathrm{hS}$ & $\mathrm{sM}, \mathrm{Bl}(+)$ & $\mathrm{hS}$ & $\mathrm{sM}, \mathrm{Bl}(+)$ & $\mathrm{hS}$ \\
\hline Roxinho 1 & CE 73 & $\mathrm{mM}(+)$ & $\mathrm{R}$ & sM,Bl (+) & $\mathrm{hS}$ & $\mathrm{mM}(+)$ & $\mathrm{R}$ & $\mathrm{sM}, \mathrm{Bl}(+)$ & $\mathrm{hS}$ & sM,Bl (+) & $\mathrm{hS}$ & $\mathrm{mM}(+)$ & $\mathrm{R}$ & $\mathrm{sM}, \mathrm{Bl}(+)$ & $\mathrm{hS}$ \\
\hline Roxinho 2 & CE 77 & $\mathrm{mM}(+)$ & $\mathrm{R}$ & sM,Bl (+) & $\mathrm{hS}$ & $\mathrm{M}(+)$ & $\mathrm{S}$ & $\mathrm{sM}, \mathrm{Bl}(+)$ & $\mathrm{hS}$ & sM,Bl (+) & $\mathrm{hS}$ & $\mathrm{mM}(+)$ & $\mathrm{R}$ & sM,Bl (+) & $\mathrm{hS}$ \\
\hline Sempre Verde & CE 25 & $\mathrm{mM}(+)$ & $\mathrm{R}$ & $\mathrm{sM}, \mathrm{Bl}(+)$ & $\mathrm{hS}$ & $\mathrm{mM}(+)$ & $\mathrm{R}$ & $\mathrm{sM}, \mathrm{Bl}(+)$ & $\mathrm{hS}$ & sM,Bl,LDit (+) & $\mathrm{hS}$ & $\mathrm{M}(+)$ & $\mathrm{S}$ & $\mathrm{sM}, \mathrm{Bl}(+)$ & $\mathrm{hS}$ \\
\hline Setentão & CE 596 & $\mathrm{mM}(+)$ & $\mathrm{R}$ & sM,Bl (+) & $\mathrm{hS}$ & $\mathrm{mM}(+)$ & $\mathrm{R}$ & $\mathrm{M}(+)$ & $\mathrm{S}$ & sM,Bl (+) & $\mathrm{hS}$ & $\mathrm{M}(+)$ & $\mathrm{S}$ & $\mathrm{M}(+)$ & $\mathrm{S}$ \\
\hline TVu 14533 & CE 444 & $\mathrm{mM}(+)$ & $\mathrm{R}$ & $\mathrm{M}(+)$ & $\mathrm{S}$ & $\mathrm{mM}(+)$ & $\mathrm{R}$ & sM,B1,SNe (+) & $\mathrm{hS}$ & sM,Bl,SNe (+) & $\mathrm{hS}$ & $\mathrm{mM}(+)$ & $\mathrm{R}$ & sM,Bl,SNe (+) & $\mathrm{hS}$ \\
\hline UCR 95701 & CE 493 & $\mathrm{mM}(+)$ & $\mathrm{R}$ & $\mathrm{M}(+)$ & $\mathrm{S}$ & $\mathrm{mM}(+)$ & $\mathrm{R}$ & sM,Bl (+) & $\mathrm{hS}$ & sM,Bl (+) & $\mathrm{hS}$ & $\mathrm{SM}(+)$ & $\mathrm{S}$ & $\mathrm{sM}, \mathrm{Bl}(+)$ & $\mathrm{hS}$ \\
\hline$[011071(01)(05)]$ & CE 819 & $\mathrm{mM}(+)$ & $\mathrm{R}$ & $\mathrm{sM}, \mathrm{Bl}(+)$ & $\mathrm{hS}$ & $\mathrm{M}(+)$ & $\mathrm{S}$ & sM,Bl,LDit (+) & $\mathrm{hS}$ & $\mathrm{M}(+)$ & $\mathrm{S}$ & $\mathrm{mM}(+)$ & $\mathrm{R}$ & $\mathrm{sM}, \mathrm{Bl}(+)$ & $\mathrm{hS}$ \\
\hline [L1325(IPA)] & CE 665 & $\mathrm{mM}(+)$ & $\mathrm{R}$ & sM,Bl (+) & $\mathrm{hS}$ & $\mathrm{sM}, \mathrm{Bl}(+)$ & $\mathrm{hS}$ & sM,Bl (+) & $\mathrm{S}$ & M (+) & $\mathrm{S}$ & $\mathrm{mM}(+)$ & $\mathrm{R}$ & $\mathrm{M}(+)$ & $\mathrm{S}$ \\
\hline 1423 P1 & CE 293 & $\mathrm{mM}(+)$ & $\mathrm{R}$ & $\mathrm{sM}(+)$ & $\mathrm{S}$ & M (+) & $\mathrm{S}$ & sM,Bl (+) & $\mathrm{hS}$ & sM,Bl,LDit (+) & $\mathrm{hS}$ & $\mathrm{mM}(+)$ & $\mathrm{R}$ & sM,B1,RF (+) & $\mathrm{hS}$ \\
\hline 1962 & CE 311 & $\mathrm{mM}(+)$ & $\mathrm{R}$ & sM,Bl (+) & $\mathrm{hS}$ & $\mathrm{mM}(+)$ & $\mathrm{R}$ & sM,Bl,SNe (+) & $\mathrm{hS}$ & sM,Bl,PDft (+) & $\mathrm{hS}$ & $\mathrm{mM}(+)$ & $\mathrm{R}$ & sM,Bl,Mt (+) & $\mathrm{hS}$ \\
\hline 7917 Dixie hee & CE 104 & $\mathrm{mM}(+)$ & $\mathrm{R}$ & M (+) & $\mathrm{S}$ & $\mathrm{M}(+)$ & $\mathrm{S}$ & sM,Bl,LDit (+) & $\mathrm{hS}$ & $\mathrm{M}(+)$ & $\mathrm{S}$ & $\mathrm{mM}(+)$ & $\mathrm{R}$ & sM,Bl (+) & $\mathrm{hS}$ \\
\hline
\end{tabular}

${ }^{(1)}$ Bl, blistering; LDit, leaf distortion; LL, local lesions; M, mosaic; mM, mild mosaic; PDft, plant death; sM, severe mosaic; SNe, systemic necrosis; NS, no symptom. ${ }^{(2)}$ I, immune; R, resistant; S, susceptible; hS, highly susceptible. 
fragment of $593 \mathrm{bp}$ was amplified from susceptible CPSMV infected cowpea genotypes, no amplified fragments were detected in the PCR products of the inoculated immune cowpea genotypes. PCR results were also important to confirm the serological efficiency for determining the absence of CPSMV in inoculated plants, indicating that immune reaction can be efficiently identified by serology through double immune diffusion tests. The immunity or extreme resistance of genotype CNC 0434 to CPSMV was originally reported by Rios \& Neves (1989). Similar characteristics were also found in the cowpea line L254.008 for the CPSMV $\mathrm{Re}_{1}$ isolate obtained in the State of Alagoas, with absence of symptoms and no virus recovering in Chenopodium quinoa L. back-inoculated from asymptomatic plants (Assunção et al., 2005). Assunção et al. (2005) concluded that the CPSMV resistance gene of CNC 0434 was different from that found in line L254.008, but the same as that of 'Macaibo'.

However, the results obtained in the present study indicate that the CNC 0434 and 'Macaibo' genes for immunity to CPSMV isolates are likely different, since CNC 0434 was shown to be immune to all CPSMV isolates, including $\mathrm{CPSMV}_{\mathrm{MC}}$, while 'Macaibo' was infected by CPSMV $_{M C}$. Rocha et al. (2003) also identified source of immunity to CPSMV in cowpea genotypes with white seed coats.

These results are strong evidence of the existence of more than one gene for controlling the inheritance of immunity to CPSMV isolates in cowpea. Although controlled by only a pair of recessive genes (Vale \& Lima, 1995), the immunity of 'Macaibo' to CPSMV has been stable over the years (Lima et al., 2005b; Camarço et al., 2009). Umaharan et al. (1997), by backcrossing of immune and susceptible cowpea cultivars, showed that immunity to CPSMV is determined by three independent dosage dependent genes.

The existence and the identification of more than one gene for controlling immunity or extreme resistance to CPSMV will pave the way for breeders to produce cowpea genotypes with multiple resistances to more than one virus isolate. According to Fan (2008), the Arlington line of cowpea is known to show extreme resistance to Cowpea mosaic virus (CPMV), another member of the genus Comovirus, with no virus recovered and no observed symptoms. Extreme resistance or immunity has been known to be controlled by RNA1, which corresponds to the largest of the two CPMV genomic RNAs (Fan, 2008). Silva (2008) identified molecular markers associated to the CPSMV resistance gene in cowpea.

Some genotypes showed resistance to CPSMV isolates, delaying the appearance of symptoms, especially to $\mathrm{CPSMV}_{\mathrm{MC}}$, which could be recommended for its control. Booker et al. (2005) concluded that control measures should be aimed at delaying infection by CPSMV to minimize the impact on cowpea yield.

Although none of the genotypes showed multiple immunity to all virus isolates, some deserve special attention as sources of multiple immunity and resistance to all isolates of one or two viruses. The genotype CNCx284-66E, immune to all CPSMV isolates, was also immune to both CABMV isolates and resistant to CMV. This genotype did not exhibit symptoms after inoculation with the CABMV and CPSMV isolates and showed only mild mosaic when inoculated with CMV. Furthermore, the CABMV and CPSMV isolates were not detected by serology and PCR in the inoculated CNCx284-66E plants. The genotypes CNCx172-3E/P and $\mathrm{CNCx} 249-272 \mathrm{~F}$ showed immunity to CPSMV and resistance to $\mathrm{CMV}$ and $\mathrm{CABMV}$ isolates. The symptom reactions of the cowpea genotypes also indicated that a greater number of genotypes was susceptible to $\mathrm{CPSMV}_{\mathrm{CE}}, \mathrm{CPSMV}_{\mathrm{CROT}}$, and CPSMV $\mathrm{PB}$ than to $\mathrm{CPSMV}_{\mathrm{MC}}$.

Since the development of resistant cultivars has been universally considered the most effective method for controlling cowpea virus diseases (Hampton et al., 1997;

Table 2. Number of immune, resistant, susceptible and highly susceptible cowpea (Vigna unguiculata) genotypes to isolates of Cowpea aphid-borne mosaic virus (CABMV), Cowpea severe mosaic virus (CPSMV), and Cucumber mosaic virus (CMV).

\begin{tabular}{lccccccc}
\hline Behavior & CABMV $_{\mathrm{CASC}}$ & CABMV $_{\text {FORT }}$ & CPSMV $_{\mathrm{CE}}$ & CPSMV $_{\mathrm{MC}}$ & CPSMV $_{\mathrm{CROT}}$ & CPSMV $_{\text {PB }}$ & CMV \\
\hline Immune & 3 & 2 & 7 & 5 & 7 & 2 & 7 \\
Resistant & 8 & 21 & 2 & 15 & 2 & 2 & 29 \\
Susceptible & 14 & 9 & 5 & 11 & 8 & 4 & 1 \\
Highly susceptible & 8 & 1 & 19 & 2 & 16 & 20 & 0 \\
\hline
\end{tabular}


Assunção et al., 2005; Lima et al., 2005b), the sources of resistance to more than one virus isolate, notably the genotypes $\mathrm{CNCx} 284-66 \mathrm{E}$ and $\mathrm{CNCx} 251-11 \mathrm{E}$, are a good alternative for the production of new cowpea cultivars with more stable and broader resistance to viruses. Additionally, both genotypes have brown and rhomboid seeds, usually preferred by the consumer market.

\section{Conclusions}

1. The majority of the cowpea genotypes is immune or resistant to $\mathrm{CMV}$, showing only mild mosaic symptoms after inoculation.

2. $\mathrm{CPSMV}_{\mathrm{MC}}$ causes less severe symptoms on most of the cowpea genotypes, in spite of infecting the cultivar Macaibo, which is immune to all other CPSMV isolates.

3. PCR results are important for determining the absence of CPSMV isolates in inoculated plants, and serology is efficient in determining the immune reaction in cowpea genotypes.

4. The genes for immunity to CPSMV isolates of the cowpea genotypes CNC 0434 and 'Macaibo' are likely different, since CNC 0434 is immune to all CPSMV isolates, including $\mathrm{CPSMV}_{\mathrm{MC}}$, and 'Macaibo' is infected only by $\mathrm{CPSMV}_{\mathrm{MC}}$.

\section{Acknowledgements}

To Fundação Cearense deApoio ao Desenvolvimento Científico e Tecnológico, for the financial support.

\section{References}

ALMEIDA, A.M.R.; LIMA, J.A. de A. Princípios e técnicas de diagnose aplicados em fitovirologia. Fortaleza: Sociedade Brasileira de Fitopatologia, 2001. 186p.

ANDERSON, E.J.; KLINE, A.S.; MORELOCK, T.E.; MCNEW, R.W. Tolerance to blackeye cowpea mosaic potyvirus not correlated with decreased virus accumulation or protection from cowpea stunt disease. Plant Disease, v.80, p.847-852,1996.

ASSUNÇÃO, I.P.; M.-FILHO, L.R.; RESENDE, L.V.; BARROS, M.C.S., LIMA, G.S.A.; COELHO, R.S.B.; LIMA, J.A.A. Genes diferentes podem conferir resistência ao Cowpea severe mosaic virus em caupi. Fitopatologia Brasileira, v.30, p.274-278, 2005.

BOOKER, H.M.; UMAHARAN, P.; MCDAVID, C.R. Effect of Cowpea severe mosaic virus on crop growth characteristics and yield of cowpea. Plant Disease, v.89, p.515-520, 2005.
CAMARÇO, R.F.E.A.; NASCIMENTO, A.K.Q. do; ANDRADE, E.C.; LIMA, J.A.A. Biological, serological and molecular comparison between isolates of Cowpea severe mosaic virus. Tropical Plant Pathology, v.34, p.239-244, 2009.

FAN, Q. Characterization of the Cowpea mosaic virus RNA1-encoded elicitor of extreme resistance in cowpea. 2008. 122p. Dissertation (Ph.D.) - University of California, Davis.

FREIRE FILHO, F.R.; RIBEIRO, V.Q.; BARRETO, P.D.; SANTOS, A.A. Melhoramento Genético. In: FREIRE-FILHO, F.R.; LIMA, J.A. de A.; RIBEIRO, V.Q. (Ed.). Feijão caupi: avanços tecnológicos. Brasília: Embrapa Informação Tecnológica, 2005. p.2-92.

GHORBANI, S.G.M.; SHAHRAEIN, N.; ELAGINIA, S.A. Serodiagnosis of cowpea (Vigna unguiculata) viruses in Guilan province, Iran. Iranian Journal of Virology, v.1, p.28-31, 2008.

GOWDA, B.S.; MILLER, J.L.; RUBIN, S.S.; SHARMA, D.L; TIMKO, M.P. Isolation, sequencing, and mapping of resistance gene analogs from cowpea (Vigna unguiculata L.). In: FATOKUN, C.A.; TARAWALI, S.A.; SINGH, B.B.; KORMAWA, P.M.; TAMÒ, M. (Ed.). Challenges and opportunities for enhancing sustainable cowpea production. Ibadan: International Institute of Tropical Agriculture, 2000. p.167-184.

HAMPTON, R.O.; THOTTAPPILLY, G.; ROSSEL, H.W. Viral disease of cowpea and their control by resistance-conferring genes. In: SINGH, B.B.; MOHAN RAJ, D.R.; DASHIELL, K.E.; JACKAI, L.E.N. (Ed.). Advances in cowpea research. Ibadan: International Institute of Tropical Agriculture, 1997. p.159-175.

KANG, B.-C.; YEAM, I.; JAHN, M.M. Genetics of plant virus resistance. Annual Review of Phytopathology, v.43, p.581-621, 2005.

LIMA, J.A.A.; NASCIMENTO, A.K.Q.; SILVA, G.S.; CAMARÇO, R.F.E.A.; GONÇALVES, M.F.B. Crotalaria paulinea, novo hospedeiro natural do vírus do mosaico severo do caupi. Fitopatologia Brasileira, v.30, p.429-433, 2005a.

LIMA, J.A.A.; NELSON, M.R. Purificação e identificação sorológica de "Cowpea mosaic virus" em Vigna sinensis Endl. no Ceará. Ciência Agronômica, v.3, p.5-8, 1973.

LIMA, J.A.A.; SANTOS, C.D.G.; SILVEIRA, L.F.S. Comportamento de genótipos de feijão-de-corda em relação aos dois principais vírus que ocorrem no Ceará. Fitopatologia Brasileira, v.11, p.151-161, 1986.

LIMA, J.A.A.; LIMA, R.C.A.; GONÇALVES, M.F.B.N.; SITTOLIN, I.M. Biological and serological characteristics of a genetically different Cowpea severe mosaic virus strain. Virus: Reviews and Research, v.3, p.57-65, 1998.

LIMA, J.A.A.; SITTOLIN, I.M.; LIMA, R.C.A. Diagnose e estratégias de controle de doenças ocasionadas por vírus. In: FREIRE-FILHO, F.R.; LIMA, J.A. de A.; RIBEIRO, V.Q. (Ed.). Feijão caupi: avanços tecnológicos. Brasília: Embrapa Informação Tecnológica, 2005b. p.404-459.

PIO-RIBEIRO, G.; ASSIS FILHO, M.F.; ANDRADE, G.P. Doenças do caupi. In: KIMATI, H.; AMORIM, L.; REZENDE, J.A.M.; BERGAMIN FILHO, A.; CAMARGO, L.E.A. (Ed.). 
Manual de fitopatologia: doenças das plantas cultivadas. 4.ed. São Paulo: Agronômica Ceres, 2005. p.215-216.

PIO-RIBEIRO, G.; WYATT, S.D.; KUHN, C.W. Cowpea stunt: a disease caused by synergistic interaction of two viruses. Phytopathology, v.68, p.1260-1265, 1978.

RIOS, G.P.; NEVES, B.P. das. Dispersão do vírus do mosaico severo do caupi. Fitopatologia Brasileira, v.14, p.20-25, 1989.

ROCHA, M. de M.; LIMA, J.A. de A.; FREIRE-FILHO, F.R.; ROSAL, C.J. de S.; LOPES, Â.C. de A. Resistência de genótipos de caupi (Vigna unguiculata L. Walp) de tegumento branco a isolados de vírus das famílias Bromoviridae, Comoviridae e Potyviridae. Revista Científica Rural, v.8, p.85-92, 2003.

ROTT, M.E.; JELKMANN, W. Characterization and detection of several filamentous viruses of cherry: adaptation of an alternative cloning method (DOP-PCR), and modification of an RNA extraction protocol. European Journal of Plant Pathology, v.107, p.411-420, 2001.
SILVA, E.K.C. e. Cowpea severe mosaic virus: diagnóstico, estudo da herança e identificação de marcadores moleculares associados à resistência. 2008. 72p. Dissertação (Mestrado) - Universidade Federal Rural de Pernambuco, Recife.

SINGH, B.B.; EHLERS, J.D.; SHARMA, B.; FREIRE FILHO, F.R. Recent progress in cowpea breeding. In: FATOKUN, C.A.; TARAWALI, S.A.; SINGH, B.B.; KORMAWA, P.M.; TAWO, M. (Ed.). Challenges and opportunities for enhancing sustainable cowpea production. Ibadan: International Institutes of Tropical Agriculture, 2000. p.22-40.

UMAHARAN, P.; ARIYANAYAGAM, R.P.; HAQUE, S.Q. Resistance to Cowpea severe mosaic virus, determined by three dosage dependent genes in Vigna unguiculata L.Walp. Euphytica, v.95, p.49-55, 1997.

VALE, C.C.; LIMA, J.A.A. Herança de imunidade da cultivar Macaibo de Vigna unguiculata ao vírus do mosaico severo do caupi. Fitopatologia Brasileira, v.20, p.30-32, 1995.

$\overline{\text { Received on July 12, } 2011 \text { and accepted on October 31, } 2011}$ 